\section{Efficacy of Extracorporeal Shock Wave Therapy in the Treatment of Achilles Tendinopathy: Clinical and Functional Outcomes}

\author{
Aşil Tendinopatisinin Tedavisinde Ekstrakorporeal \\ Şok Dalga Tedavisinin Etkililiği: Klinik ve \\ Fonksiyonel Sonuçlar
}

\begin{abstract}
Aim: Chronic Achilles tendinopathy (AT) is one of the most common tendon pathologies, and conservative treatment often fails to produce satisfactory results. This study aimed to investigate the efficacy of extracorporeal shock wave therapy (ESWT) in chronic and refractory AT. Materials and Methods: A total of 195 patients who had undergone ESWT for AT refractory to standard conservative treatment were assessed retrospectively, and 64 patients (64 feet) who met our eligibility criteria were included. The patients underwent three sessions of ESWT, each with 2000 pulses at a dose of $0.06-0.12 \mathrm{~mJ} / \mathrm{mm} 2$ (low-dose). Pain levels and clinical/functional scores were measured before the treatment (BT) and at the 3rd and 12th weeks of the last session, by using the Visual Analogue Scale (VAS) and the American Orthopedic Foot and Ankle Society (AOFAS) scoring system.

Results: Of the 64 patients included, 48 were female and 16 were male. The mean patient age was 47.9 years. There was improvement in pain, the mean VAS scores changing from 7.4 (5-10) BT to $4(2-7)$ at week $3(p<0.001)$ and $1.5(0-6)$ at week $12(p<0.001)$. The mean AOFAS scores were also improved, changing from $60(48-75)$ BT to $74.8(62-90)$ at week $3(p<0.001)$ and 86.6 $(62-100)$ at week $12(p<0.001)$. There was no statistically significant difference between male and female patients with respect to the improvement recorded in the VAS scores $(p=0.163)$. Discussion and Conclusion: Low-dose ESWT can produce successful clinical results in the treatment of chronic AT refractory to standard conservative treatment.

Keywords: Achilles tendon; AOFAS; ESWT; tendinopathy; VAS
\end{abstract}

\section{Öz}

Amaç: Kronik Aşil tendinopatisi (AT) en sık görülen tendon patolojilerindendir ve konservatif tedavi çoğunlukla tatmin edici sonuçlar vermez. Bu çalışmada ekstrakorporeal şok dalga tedavisinin (ESWT) kronik ve refrakter AT'deki etkililiğini araştırmak amaçlanmıştır.

Gereç ve Yöntemler. Standart konservatif tedaviye refrakter AT nedeniyle ESWT uygulanmış olan 195 hasta geriye dönük olarak incelendi ve uygunluk kriterlerimize uyan 64 hasta (64 ayak) çalışmaya dahil edildi. Hastalara, her seansta 0,06-0,12 mJ/mm2 (düşük doz) dozunda 2000 atım olacak şekilde, 3 seans ESWT uygulandı. Ağrı düzeyleri ve klinik/fonksiyonel skorlar Görsel Analog Skalası (VAS) ve Amerikan Ortopedik Ayak ve Ayak Bileği Birliği (AOFAS) skorlama sistemi kullanılarak tedavi öncesinde (TÖ) ve son seansın 3. ve 12. haftasında ölçüldü.

Bulgular. Çalışmaya alınan 64 hastanın 48'i kadın, 16'sı erkekti ve ortalama hasta yaşı 47,9 yıl idi. Ağrıda iyileşme söz konusuydu; ortalama VAS skorlarııın TÖ 7,4'ten (5-10) 3. haftada 4'e (2-7) $(p<0,001)$ ve 12 . haftada ise $1,5^{\prime} e(0-6)(p<0,001)$ gerilediği gözlendi. Ortalama AOFAS skorlar da TÖ 60'tan (48-75) 3. haftada 74,8'e (62-90) ( $p<0,001)$ ve 12. haftada ise 86,6'ya (62-100) $(p<0,001)$ yükselmişti. Kadın ve erkek hastalar arasında VAS skorlarında kaydedilen iyileşme bakımından istatistiksel olarak anlamlı fark yoktu $(p=0,163)$.

Tartışma ve Sonuç: Düşük doz ESWT, kronik ve standart konservatif tedaviye refrakter AT tedavisinde başarılı klinik sonuçlar sağlayabilir.

Anahtar Sözcükler: AOFAS; Aşil tendonu; ESWT; tendinopati; VAS
Yalcin Turhan, Mehmet Arican Zekeriya Okan Karaduman

Duzce University Medical Faculty Orthopedics and Traumatology Department

Received/Geliş : 08.08.2018 Accepted/Kabul: 20.10 .2018

DOI: 10.21673/anadoluklin.452068

Corresponding author/Yazışma yazarı Yalçın Turhan

Duzce University Medical Faculty

Orthopedics and Traumatology Department, Konuralp, 81110 Duzce, Turkey

E-mail:yturhan_2000@yahoo.com 


\section{INTRODUCTION}

Achilles tendinopathy (AT) is a common tendon pathology that mostly affects professional athletes and sedentary persons. The main complaint is heel and tendon pain, especially during exercising. The risk of developing AT increases in case of repetitive movements and trauma (1). The injury begins with inflammation around the tendon (peritendinitis) and can progress to tendinitis (2). The initial treatment should be conservative and include pain and inflammation control, functional malalignment correction, and rehabilitation of the gastro-soleus muscle complex (3). In some cases with severe acute symptoms, immobilization of the ankle joint for 7 to 10 days might be indicated (4). Surgical treatment is needed in only a small number of patients, and the literature lacks prospective randomized studies comparing conservative and surgical treatment outcomes (5).

Extracorporeal shock wave therapy (ESWT) is a conservative treatment modality shown to be helpful in some patients with musculoskeletal conditions and AT (6). Since the 1990s, it has gained increasing popularity worldwide as a tool in the treatment of soft tissue conditions like humeral epicondylitis and plantar fasciitis (7) and in the management of musculoskeletal complaints.

In this study, we aimed to investigate the efficacy and clinical and functional outcomes of ESWT in the treatment of refractory AT.

\section{MATERIALS AND METHODS}

\section{Sample selection}

This study was designed as a retrospective observational study and was approved by the ethics committee of Düzce University Medical Faculty (no. 2018/65).

A total of 195 patients who had undergone ESWT for refractory AT between December 2009 and December 2017 at the outpatient clinic of our Orthopedics and Traumatology Department were assessed. Refractory AT was described as persistent irritation of the tendon, tenosynovium, or tendon insertion which had impaired daily activities for $>6$ months and not responded to standard conservative treatment. All patients underwent plain radiography before ESWT.

The exclusion criteria were as follows: pregnancy, history of foot surgery and foot/ankle fracture, calcified Achilles tendon in radiography, lower extremity neuropathies, $<18$ or $>70$ years of age, and bilateral disease. Patients with bilateral involvement were not included in our study to avoid problems of noncompliance during evaluation. Ultimately, 64 patients (64 feet), who met our eligibility criteria (unilateral involvement, undergoing ESWT at weekly intervals for 3 weeks, and availability of complete patient data) were included. All patients gave informed consent to the scientific use of their medical data.

\section{Treatment protocol}

Treatments were performed using a Swiss Dolorclast Master ESWT machine (EMS Electro Medical Systems, Nyon, Switzerland), which produced radial shockwaves. Each patient underwent three sessions of radial ESWT (each with 2000 pulses at a dose of $0.06-0.12 \mathrm{~mJ} / \mathrm{mm}^{2}$ ), administered weekly for three weeks.

\section{Clinical assessment}

Pain levels and clinical/functional scores were measured by the Visual Analogue Scale (VAS) and the American Orthopedic Foot and Ankle Society (AOFAS) scoring systems, respectively. Repetitive measurements were performed before the treatment and at the $3^{\text {rd }}$ and $12^{\text {th }}$ weeks of the last session. The VAS is a useful scale for measuring pain on a continuum. The simple VAS is a straight, horizontal line of a fixed length, usually 100 $\mathrm{mm}$. AOFAS measures functionality (50 points), pain (40 points), and alignment (10 points), a total of 100 points representing the best result (8).

\section{Statistical analysis}

One-way ANOVA was used to analyze the change in the time-dependent measurements. Two-way ANOVA was used to examine the variation of the time-dependent measures relative to groups. All analyses were performed by using the Statistical Package for Social Sciences (v. 22) software (SPSS, Chicago, IL, US). $\mathrm{p}<0.05$ was considered statistically significant.

\section{RESULTS}

Of the 64 patients included, 48 (75\%) were female and 16 (25\%) were male. The mean patient age was 47.9 years. The affected tendon was the right one in 36 patients and the left in 28.

The VAS scores were measured before the treatment (BT) and at week 3 and week 12. A scoring from 0 to 10 was made. There was statistically significant improvement in pain, the mean scores changing from $7.4(5-10)$ BT to $4(2-7)$ at week $3(\mathrm{p}<0.001)$ and $1.5(0-6)$ at week $12(\mathrm{p}<0.001)$. 
Table 1. The relationship between the VAS and AOFAS scores BT and at week 3 and week 12 .

\begin{tabular}{lcccc}
\hline & & AOFAS (BT) & AOFAS (week 3) & AOFAS (week 12) \\
\hline \multirow{3}{*}{ VAS (BT) } & Pearson Correlation & -.755 & -.454 & -.336 \\
& Sig. (2-tailed) & .000 & .000 & .007 \\
\multirow{2}{*}{ VAS (week 3) } & $\mathrm{N}$ & 64 & 64 & 64 \\
& Pearson Correlation & -.497 & -.752 & -.739 \\
& Sig. (2-tailed) & .000 & .000 & .000 \\
VAS (week 12) & $\mathrm{N}$ & 64 & 64 & 64 \\
& Pearson Correlation & -.357 & -.584 &. .885 \\
& Sig. (2-tailed) & .004 & .000 & .000 \\
\hline
\end{tabular}

The AOFAS scores were also measured BT and at week 3 and week 12. There was statistically significant improvement in the mean scores: from $60(48-75)$ BT to $74.8(62-90)$ at week $3(\mathrm{p}<0.001)$ and $86.6(62-100)$ at week $12(\mathrm{p}<0.001)$.

There was a statistically significant inversely proportional relationship between the VAS and AOFAS scores BT and at week 3 and week 12 (Table 1).

There was no statistically significant difference between male and female patients with respect to the improvement recorded in the VAS scores $(p=0.163)$. Although statistically insignificant, the male patients showed a better AOFAS-score improvement from week 3 to week 12 , compared to the female patients $(\mathrm{p}=0.029)$.

\section{DISCUSSION AND CONCLUSION}

The Achilles tendon is the longest tendon in the human body with no tendon sheath but rather a highly vascularized paratenon, and the blood supply mostly comes from the vessels within this structure. There is also a relatively avascular area, approximately $5 \mathrm{~cm}$ proximal to the calcaneus insertion, as the site most prone to tendinopathy (9). AT is thought to be related to failure in the healing potential of the Achilles tendon because of poor vascularity and ongoing mechanical stress due to excessive loading (10). The risk factors include male sex, advanced age, mechanical lower extremity abnormalities, obesity, diabetes, excessive training, and inappropriate footwear (11). Although male sex and advanced age are known risk factors, our study was marked by a female predominance (75\%) and included only 6 patients (9.3\%) over the age of 65 .

The treatment in AT should be initiated conservatively, first utilizing activity modification, stretching, administration of non-steroidal anti-inflammatory drugs (NSAIDs), physiotherapy, and even immobilization of the ankle joint for a short period of time $(12,13)$. In chronic and refractory cases unresponsive to conservative management, surgical treatment has been an option, though with limited benefit $(14,15)$. ESWT has recently been regarded as an alternative in refractory cases prior to surgical intervention (16-19).

Along with its use to treat kidney stones and soft tissue conditions like humeral epicondylitis, plantar fasciitis, and calcifying tendinopathy of the rotator cuff $(20,21)$, ESWT has been utilized in the treatment of chronic and refractory AT with conflicting results. Perlick et al. reported lower success rates with low-dose ESWT (22). In a study by Lakshmanan et al., 15 patients scheduled for surgery due to refractory AT were treated with ESWT and good to excellent results were achieved (17). In a controlled study by Furia et al., ESWT was found to be more effective than the other conservative methods (23). The patients in our study benefited from ESWT treatment with considerable improvement in the symptoms of pain and reduced functionality. The positive results observed can be attributed to the patients having homogenous diagnoses and being treated in a single center with a standard protocol.

In our study, we used low-energy shock waves in accordance with the dosage described by Speed, who established $0.12 \mathrm{~mJ} / \mathrm{mm}^{2}$ as the cut-off value between lowenergy and high-energy shock wave therapy (24). Rompe et al. reported that the tendon's response to shock waves depended on the dosage, and that high-energy shock wave therapy was therapeutically more effective. However, with high doses, local anesthesia might be required because of the severe pain likely to be induced, and doses above $0.60 \mathrm{~mJ} / \mathrm{mm}^{2}$ can even necrotize the tendon (25). In our study, each patient underwent three sessions of low-energy radial ESWT (each with 2000 pulses at a dose of $0.06-0.12 \mathrm{~mJ} / \mathrm{mm}^{2}$ ), administered weekly for three weeks, and none of the cases required local anesthesia.

Due to its retrospective nature, the present study has several limitations. The medical records reviewed pro- 
vided no information concerning the patients' body mass index, comorbidity status, and dominant extremity. The actual level of activity, which plays an important role in AT pathophysiology, could not be considered either (26). However, since all patients in this study were advised to reduce their activity level as far as possible, we think that this parameter had little impact on our results.

In conclusion, the VAS and AOFAS assessments showed a significant improvement in the symptoms of patients with AT after treatment with ESWT, which seems to be an effective therapeutic alternative when conservative treatment fails. However, there is still a need for studies comparing high- and low-energy shock wave therapy, and single- and multiple-treatment protocols are needed to determine the optimal treatment parameters.

\section{Statement of Conflict of Interest}

The authors have no conflict of interest to declare.

\section{REFERENCES}

1. Magnan B, Bondi M, Pierantoni S, Samaila E. The pathogenesis of Achilles tendinopathy: a systematic review. Foot Ankle Surg. 2014;20(3):154-9.

2. Arner O, Lindholm A, Orell SR. Histologic changes in subcutaneous rupture of the Achilles tendon. Acta Chir Scand. 1958;116(5-6):484-90.

3. Jarvinen TA, Kannus P, Paavola M, Jarvinen TL, Jozsa L, Jarvinen M. Achilles tendon injuries. Curr Opin Rheumatol. 2001;13(2):150-5.

4. Leach RE, James S, Wasilewski S. Achilles tendinitis. Am J Sports Med. 1981;9(2):93-8.

5. Maffulli N, Sharma P, Luscombe KL. Achilles tendinopathy: etiology and management. J R Soc Med. 2004;97(10):472-6.

6. Rompe JD, Furia J, Maffulli N. Eccentric loading versus eccentric loading plus shock-wave treatment for midportion Achilles tendinopathy: a randomized controlled trial. Am J Sports Med. 2009;37(3):463-70.

7. Chung B, Wiley JP. Extracorporeal shockwave therapy: a review. Sports Med. 2002;32(13):851-65.

8. Kitaoka HB, Alexander IJ, Adelaar RS, Nunley JA, Myerson MS, Sanders M. Clinical rating systems for the anklehindfoot, midfoot, hallux, and lesser toes. Foot Ankle Int. 1994;15(7):349-53.

9. Wilson M, Stacy J. Shock wave therapy for Achilles tendinopathy. Curr Rev Musculoskelet Med. 2011;4(1):6-10.

10. Van Dijk CN, van Sterkenberg MN, Wiegerinck JI, Karlsson J, Maffulli N. Terminology for Achilles tendon related disorders. Knee Surg Sports Traumatol Arthrosc. 2011;19(5):835-41.

11. Joseph MF, Lillie KR, Bergeron DJ, Cota KC, Yoon J, Kraemer
WJ, et al. Achilles tendon biomechanics in response to acute intense exercise. J Strength Cond Res. 2014;28(5):1181-6.

12. Alfredson H, Lorentzon R. Chronic Achilles tendinosis: recommendations for treatment and prevention. Sports Med. 2000;29(2):135-46.

13. Den Hartog BD. Insertional Achilles tendinosis: pathogenesis and treatment. Foot Ankle Clin. 2009;14(4):639-50.

14. Vulpiani MC, Guzzini M, Ferretti A. Operative treatment of chronic Achilles tendinopathy. Int Orthop. 2003;27(5):30710.

15. Paavola M, Kannus P, Orava S, Pasanen M, Jarvinen $M$. Surgical treatment for chronic Achilles tendinopathy: a prospective seven month follow up study. Br J Sports Med. 2002;36(3):178-82.

16. Furia JP. High-energy extracorporeal shock wave therapy as a treatment for insertional Achilles tendinopathy. Am J Sports Med. 2006;34(5):733-40.

17. Lakshmanan P, O'Doherty DP. Chronic Achilles tendinopathy: treatment with extracorporeal shock waves. Foot Ankle Surg. 2004;10(3):125-30.

18. Mani-Babu S, Morrissey D, Waugh C, Screen H, Barton C. The effectiveness of extracorporeal shock wave therapy in lower limb tendinopathy: a systematic review. Am J Sports Med. 2015;43(3):752-61.

19. Al-Abbad H, Simon JV. The effectiveness of extracorporeal shock wave therapy on chronic Achilles tendinopathy: a systematic review. Foot Ankle Int. 2013;34(1):33-41.

20. Haake M, Deike B, Thon A, Schmitt J. Value of exact focusing of extracorporeal shock waves (ESWT) in therapy of tendonitis calcarea. A prospective randomized study. Biomed Tech. 2001;46(3):69-74.

21. Ogden JA, Alvarez R, Levitt R, Cross GL, Marlow M. Shock wave therapy for chronic proximal plantar faciitis. Clin Orthop. 2001;387:47-59.

22. Perlick L, Schiffmann R, Kraft CN, Wallny T, Diedrich O. Extracorporeal shock wave treatment of the Achilles tendonitis: experimental and preliminary clinical results. Z Orthop Ihre Grenzgeb. 2002;140(3):275-80.

23. Furia JP. Extracorporeal shockwave therapy in the treatment of chronic insertional Achilles tendinopathy. Orthopade. 2005;34(6):571-8.

24. Speed CA. Extracorporeal shock-wave therapy in the management of chronic soft-tissue conditions. J Bone Joint Surg Br. 2004;86(2):165-71.

25. Rompe JD, Kirkpatrick CJ, Küllmer K, Schwitalle M, Krischek O. Dose-related effects of shock waves on rabbit tendon Achillis: a sonographic and histological study. J Bone Joint Surg Br. 1998;80(3):546-52.

26. Sobhani S, Dekker R, Postema K, Dijkstra PU. Epidemiology of ankle and foot overuse injuries in sports: a systematic review. Scand J Med Sci Sports. 2013;23(6):669-86. 